\title{
Organocatalytic asymmetric approach to spirocyclic tetrahydrothiophenes containing either a butenolide or an azlactone structural motif
}

\author{
Joanna Hejmanowska and Lukasz Albrecht* \\ Institute of Organic Chemistry, Department of Chemistry, Lodz University of Technology, \\ Żeromskiego 116, 90-924 Lodz, Poland \\ E-mail: lukasz.albrecht@p.lodz.pl
}

DOI: http://dx.doi.org/10.3998/ark.5550190.p009.622

\begin{abstract}
In this manuscript a new organocatalytic approach to spirocyclic tetrahydrothiophenes bearing either a butenolide or an azlactone moiety is described. The developed methodology is based on the cascade reactivity of 2-mercaptoacetaldehyde (generated in situ from 1,4-dithiane-2,5-diol) with $\alpha, \beta$-unsaturated butenolides or azlactones, that consists of a thio-Michael addition followed by an intramolecular aldol reaction. Chiral bases derived from cinchona alkaloids are used as a catalyst promoting the cascade and controlling its stereochemical outcome.
\end{abstract}

Keywords: Asymmetric synthesis, organocatalysis, tetrahydrothiophenes, butenolides, azlactones

\section{Introduction}

The biological properties of organic compounds are dependent upon the presence of specific structural features. The development of methods for the efficient and selective introduction of these motifs to target molecules is highly relevant to the contemporary medicinal and organic chemistry. ${ }^{1,2}$ Notably, stereoselective strategies enabling the synthesis of enantiomerically enriched products are of particular significance as the biological properties of organic compounds are in most cases directly connected with their absolute stereochemistry. ${ }^{3,4}$ In this context, asymmetric organocatalysis, where a catalytic amount of a simple organic molecule is employed as rate-enhancer and stereochemical-inducer of a given chemical transformation is worth noticing. ${ }^{5-9}$ Decreasing the amount of generated waste and avoiding contamination of the product with a metal are among many benefits of organocatalytic reactions that are particularly important from the pharmacological industry point of view. 
Tetrahydrothiophenes, $2(3 H)$-furanones and $\alpha, \alpha$-disubstituted amino acids constitute three interesting groups of biologically relevant molecules with a broad applicability in organic chemistry (Figure 1). ${ }^{10-23}$ For instance, the tetrahydrothiophene structural motif is present in various natural products and pharmacologically active molecules (Figure 1, top). ${ }^{10-12} 2(3 H)$ Furanones, commonly known as $\Delta^{\beta, \gamma}$-butenolides, are another group of biologically relevant molecules that has been successfully applied in the target-oriented organic synthesis (Figure 1, middle). ${ }^{13-18}$ Furthermore, this group of unsaturated $\gamma$-lactones is also widely distributed in nature. Owing to their interesting biological properties, $\alpha, \alpha$-disubstituted amino acids occupy a prominent position among biologically relevant compounds (Figure 1, bottom). ${ }^{19-24}$ Notably, the azlactone moiety serves as a synthetic precursor of $\alpha, \alpha$-disubstituted amino acid and the azlactone ring opening can be accomplished under acidic conditions. ${ }^{25-31}$ Given the importance of tetrahydrothiophene, butenolide and azlactone scaffolds, the development of methods for their introduction into target molecules, in particular in a stereocontrolled manner, constitutes an important goal in modern synthetic organic chemistry.

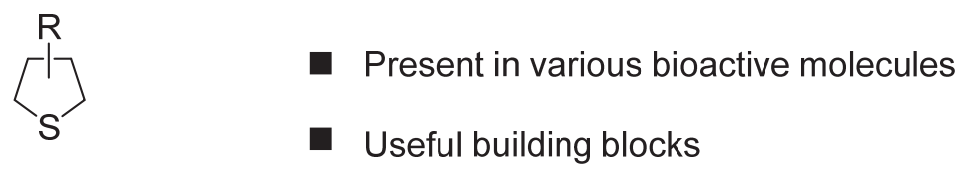

Tetrahydrothiophenes

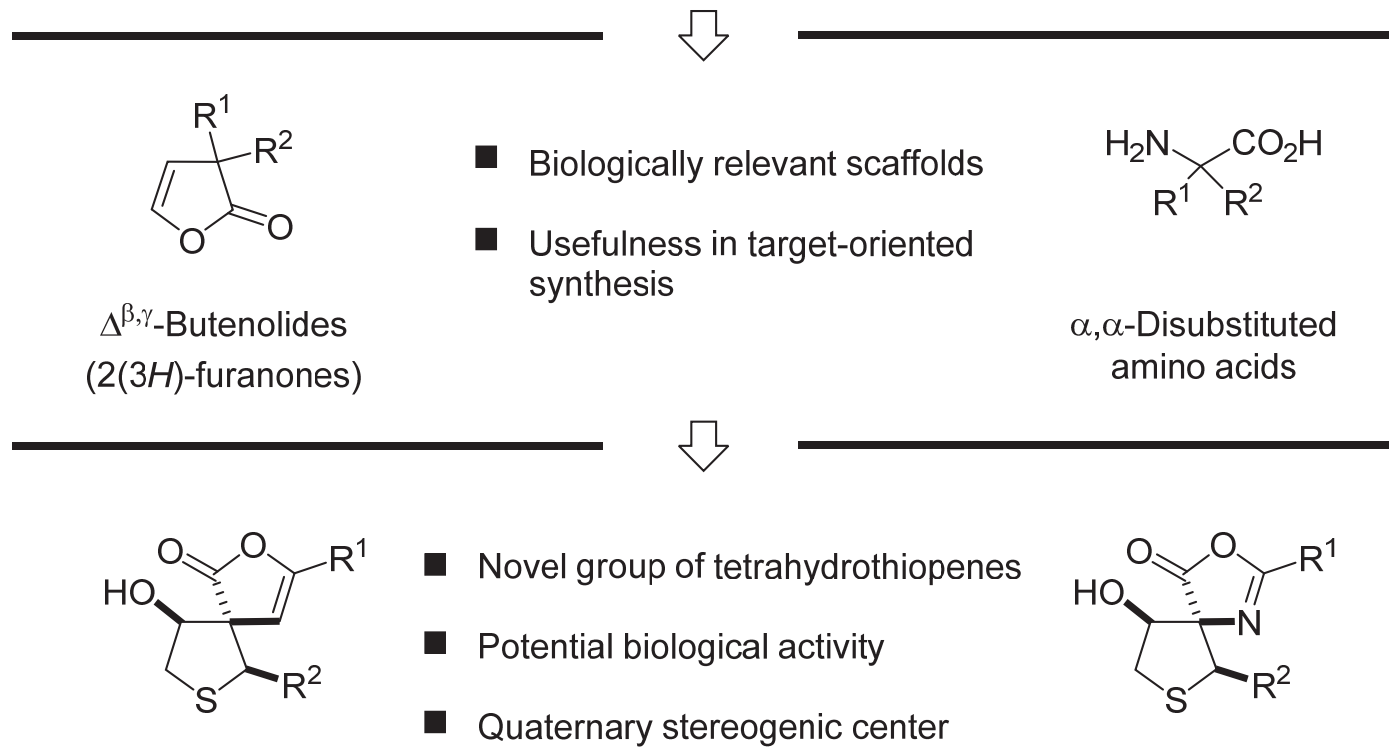

Figure 1. The importance of tetrahydrothiophene, butenolide and $\alpha, \alpha$-disubstituted amino acid structural motifs

Herein we report our studies on the development of an organocatalytic strategy leading to spirocyclic tetrahydrothiophenes $\mathbf{7}$ and $\mathbf{8}$ bearing a butenolide or azlactone structural motif (Scheme 1). The devised synthetic strategy is initiated by the thio-Michael addition of 2- 
mercaptoacetaldehyde 4 (generated in situ from 1,4-dithiane-2,5-diol 3) to 3-alkylidene-5phenylfuran-2(3H)-ones 1 or 4-alkylidene-2-phenyloxazol-5-ones 2 to give an anion 5 or $\mathbf{6}$ possessing an aromatic character. Subsequent, intramolecular aldol reaction enables the construction of a five-membered tetrahydrothiophene scaffold bearing three contiguous stereogenic centers with one being quaternary at the spiro carbon atom (for related examples of thio-Michael/aldol reaction sequences realized under organocatalytic conditions see refs 32-36). It was expected that the reaction should be possible to realize under basic conditions (for selected reviews on the enantioselective Brønsted base catalysis see refs 37-42) and the use of chiral catalyst should enable the synthesis of enantiomerically enriched products $\mathbf{7}$ and $\mathbf{8}$. Notably, the devised strategy can be categorized as a cascade reactivity (for selected reviews on organocatalytic cascade reactivities see refs 43-46) where more than one-bond is being formed in a single operation what further increases the attractiveness of the approach.
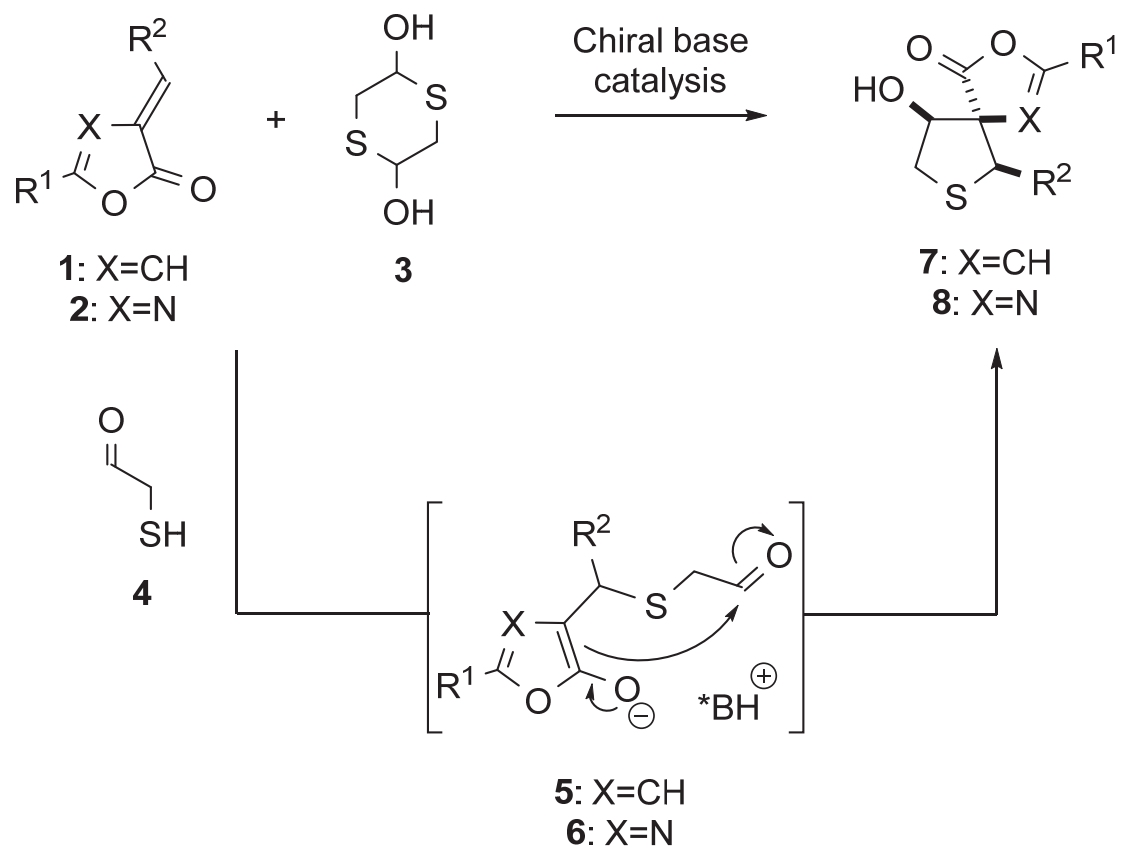

3

7: $\mathrm{X}=\mathrm{CH}$

8: $\mathrm{X}=\mathrm{N}$

Scheme 1. Synthetic objectives of our studies.

\section{Results and Discussion}

Studies were started with the goal of finding the optimal reaction conditions for the devised cascade reactivity. Initially, the sequence leading to products 7 bearing a butenolide scaffold was studied and 3-benzylidene-5-phenylfuran-2-one 1a was chosen as a model electrophile. For the ease of isolation and enantiomeric excess determination originally formed cascade product 7a was directly subjected to the acetylation reaction using acetic anhydride in the presence of triethylamine and 4-(dimethylamino)pyridine to give 9a. Catalyst screening revealed that the 
reaction proceeds under basic conditions and the application of simple cinchona alkaloid quinine 10a enables the full conversion of $\mathbf{1 a}$ with the formation of $\mathbf{9 a}$ in moderate diastereoselectivity (Scheme 2). Disappointingly, the product 9a proved almost racemic. Therefore, bifunctional cinchona-alkaloid-derived catalysts $10 \mathbf{b}$ and 10c bearing a double H-bonding unit were tested. Unsatisfactory increase of the enantioselectivity was observed using these systems. Therefore, dimeric catalysts $10 \mathbf{d}$ and 10e containing dihydroquinidine structural sub-units were evaluated in the last part of the catalyst screening. Catalyst 10d containing a pyrimidine-based linker provided product 9a with the highest enantioselectivity and was used in the further optimization studies.

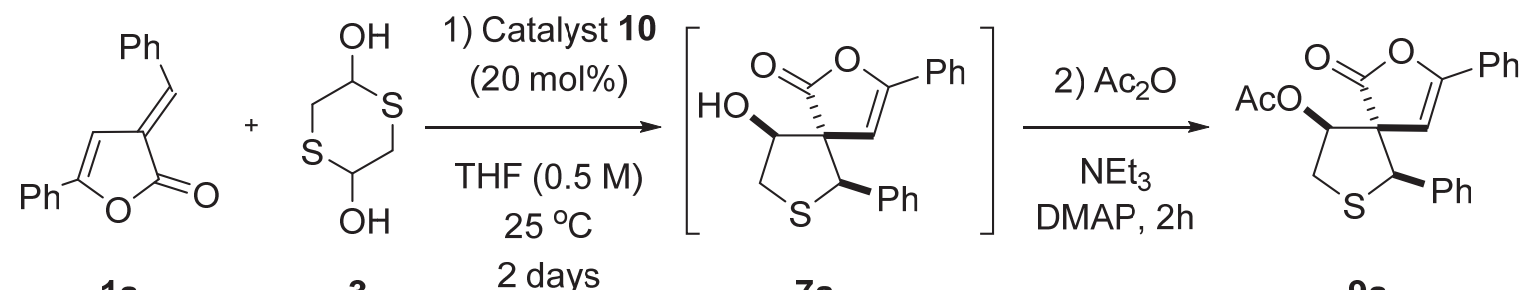

$1 a$

3

$7 a$

9a<smiles>C=CC1CC2CCN1C2[C@H](O)c1ccnc2ccc(OC)cc12</smiles>

$10 \mathrm{a}$

$>95 \%$ conv.

$5: 1 \mathrm{dr}$

$1 \%$ ee<smiles>C=CC1CC2CCC1N2C(NC(=S)NCCCCCCCCC)c1ccnc2ccc(OC)cc12</smiles>

$10 \mathrm{~b}$ $>95 \%$ conv. $5: 1 \mathrm{dr}$ $16 \%$ ee<smiles>C=CC1CC2CCN1CC2[C@H](Nc1c(NC)c(=O)c1=O)c1ccnc2ccc(OC)cc12</smiles>

$10 \mathrm{c}$

$77 \%$ conv.

$5: 1 \mathrm{dr}$

$23 \%$ ee<smiles>CCC1CN2CCC1C2[C@H](Oc1nc(-c2ccccc2)nc(O[C@H](c2ccnc3ccc(OC)cc23)C2CC3CCC2C3CC)c1-c1ccccc1)c1ccnc2ccc(OC)cc12</smiles>

10d $>95 \%$ conv.

$5: 1 \mathrm{dr}$ $29 \%$ ee<smiles>CCC1CN2CCC1CN2C(Oc1nnc(O[C@H](c2ccnc3ccc(OC)cc23)C2CC3CCC2C3CC)c2ccccc12)c1ccnc2ccc(OC)cc12</smiles>

$10 \mathrm{e}$ $>95 \%$ conv.

$5: 1 \mathrm{dr}$ $16 \%$ ee

Scheme 2. Asymmetric, organocatalytic synthesis of tetrahydrothiophenes 9 bearing a butenolide scaffold - catalyst optimization. 
Despite low enantiomeric excess obtained in this part of the screening, further studies focused on the optimization of reaction solvent, concentration, relative ratio of the reactants and temperature were undertaken (Table 1). It was found that a change of solvent had a beneficial influence on the reaction enantioselectivity (Table 1, entries 1-6). Significant increase of reaction enantioselectivity was observed in aromatic solvents with xylene (used as a mixture of regioisomers) being the optimal (Table 1, entry 6). Subsequent temperature screening (Table 1, entries 6-9) indicated that decrease of temperature led to further enhancement of the reaction enantioselectivity with the best results being obtained at $10{ }^{\circ} \mathrm{C}$ (Table 1, entry 7). The concentration effect was also evaluated in the screening studies (Table 1, entries $7,10,11$ ). It was found that both increasing and decreasing of the concentration led to deterioration of the results. Finally, the change of relative ratio of the reactants did not improve the results (Table 1, entries 12,13$)$. Therefore, the scope studies were performed at $10{ }^{\circ} \mathrm{C}$ using xylene as a solvent $(0.5 \mathrm{M})$ (Table 1 , entry 7$)$.

Table 1. Asymmetric organocatalytic synthesis of tetrahydrothiophenes 9 bearing a butenolide scaffold - optimization studies using organocatalyst 10d (Scheme 2) ${ }^{\mathrm{a}}$

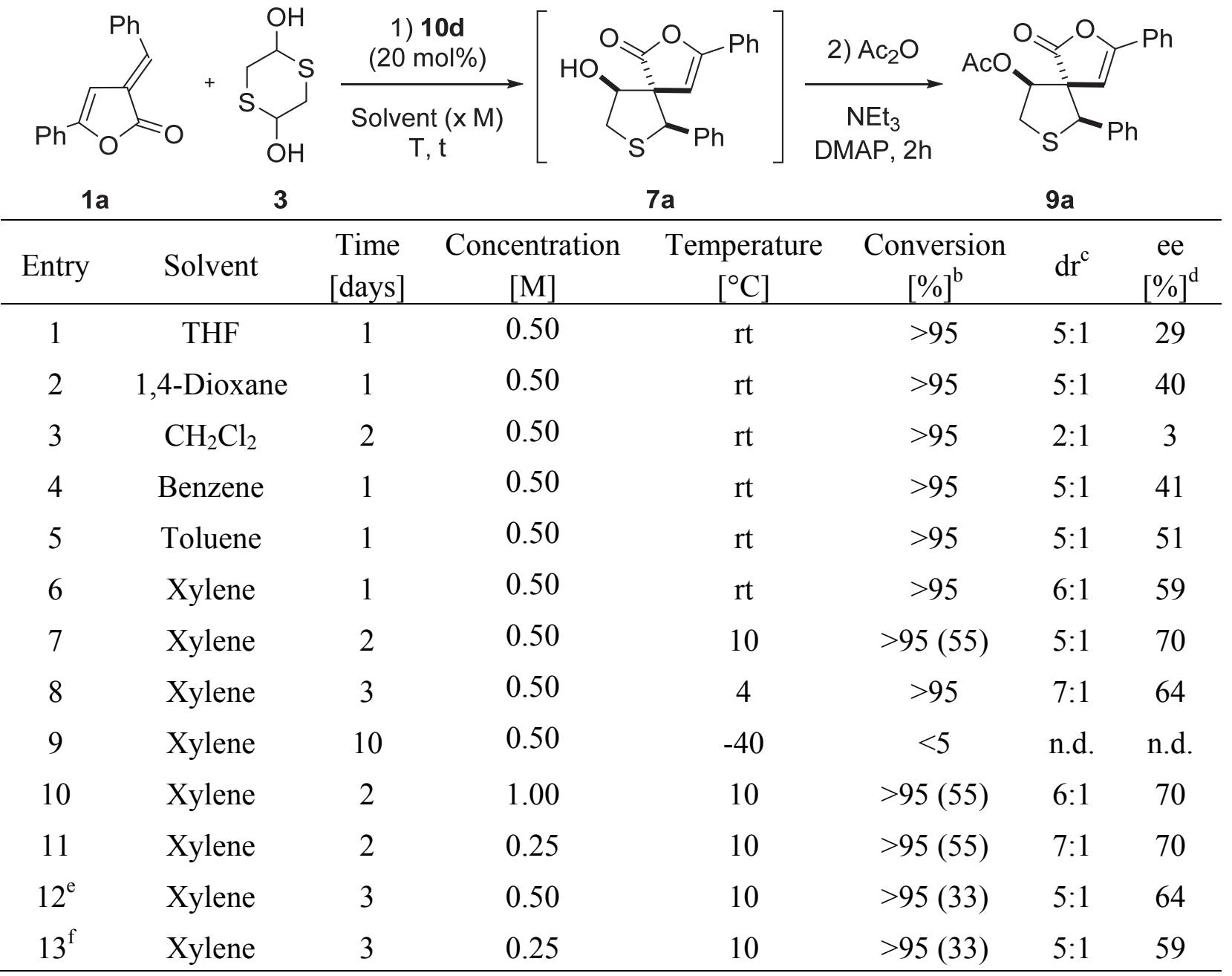


${ }^{a}$ Reactions performed on $0.1 \mathrm{mmol}$ scale using 1a (1 equiv) and 3 (1 equiv) in $0.2 \mathrm{~mL}$ of the solvent (see the Experimental Section for detailed reaction conditions). ${ }^{b}$ Determined by ${ }^{1} \mathrm{H}$ NMR of a crude reaction mixture. In parentheses the isolated yield over two step is given. ${ }^{\mathrm{c}}$ Determined by ${ }^{1} \mathrm{H}$ NMR of a crude reaction mixture. ${ }^{\mathrm{d}}$ Determined by a chiral stationary phase HPLC. Enantiomeric excesses reported for the major diastereoisomer. ${ }^{\mathrm{e}}$ Reaction performed using $1 \mathbf{a}$ ( 2 equiv) and $\mathbf{3}$ (1 equiv). ${ }^{\mathrm{f}}$ Reaction performed using $\mathbf{1 a}$ (4 equiv) and $\mathbf{3}$ (1 equiv).

With the optimization studies accomplished, the scope of the methodology was evaluated (Scheme 3). It was found that both electron-withdrawing and electron-donating substituents could be successfully introduced on the phenyl ring of the alkylidene moiety in $\mathbf{1}$ (Scheme 3, compounds 9b, 9c). Disappointingly, both the yield and enantioselectivity of the cascade decreased. However, tetrahydrothiophene $\mathbf{9 c}$ was obtained in a highly diastereoselective fashion.
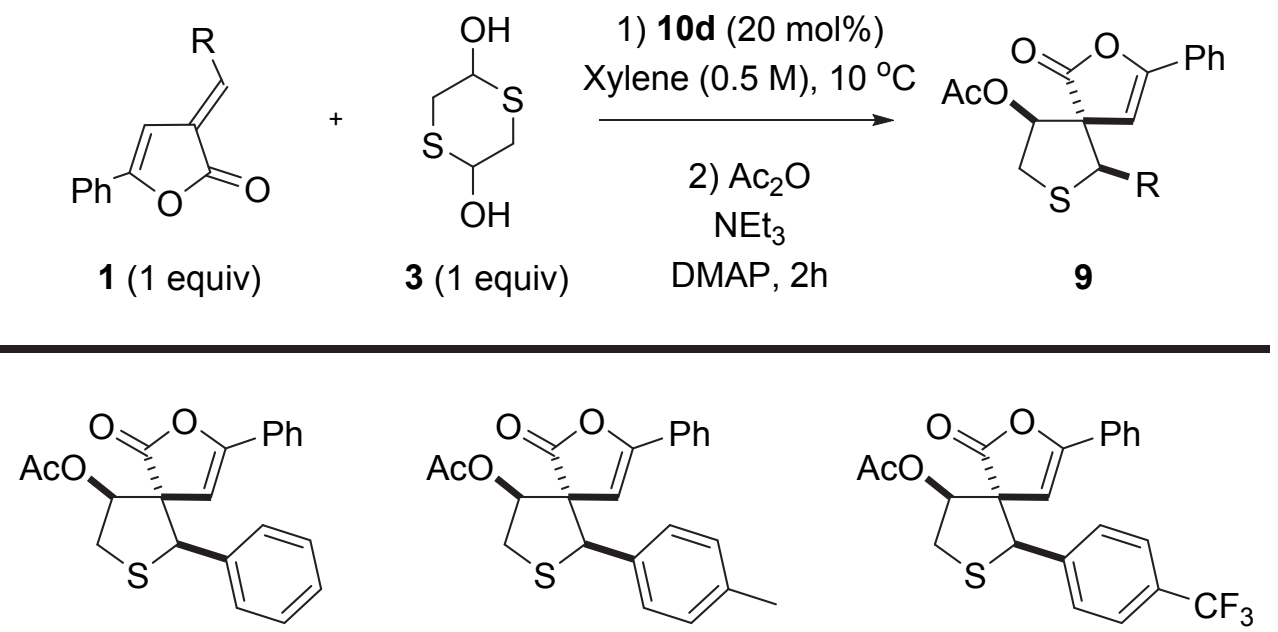

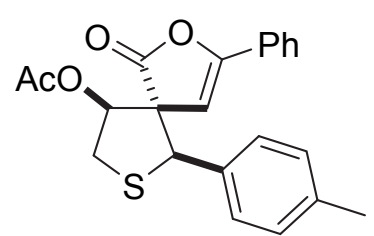

$9 \mathrm{~b}$

$38 \%$ yield

$5: 1 \mathrm{dr}$

$42 \%$ ee<smiles>CC(=O)OC1CSC(c2ccc(C(F)(F)F)cc2)C12C=C(c1ccccc1)OC2=O</smiles>

9c $35 \%$ yield $>20: 1 \mathrm{dr}$ $32 \%$ ee<smiles>CC(=O)OC1CSC(c2cccc(F)c2)C12C=C(c1ccccc1)OC2=O</smiles>

9d $52 \%$ yield 9:1 dr $58 \%$ ee<smiles>CC(=O)OC1CSC(c2ccccc2F)[C@]12C=C(c1ccccc1)OC2=O</smiles>

$9 e$ $40 \%$ yield $5: 1 \mathrm{dr}$ $21 \%$ ee

Scheme 3. Asymmetric, organocatalytic synthesis of tetrahydrothiophenes 9 bearing a butenolide scaffold - scope studies. 
In the course of further studies, the possibility to introduce substituents in various positions of the aromatic ring present in the alkylidene moiety of $\mathbf{1}$ was studied (Scheme 3, compounds 9d, 9e). Notably, while the introduction of substituent in the meta position of this aromatic moiety had no pronounced influence on the reaction outcome as demonstrated in the synthesis of 9d, the ortho-substituted isomer 9e was obtained with much lower enantioselectivity.

Given the importance of $\alpha, \alpha$-disubstituted amino acids and the usefulness of oxazolone rings as their precursors, attempts to combine the tetrahydrothiophene ring with the azlactone moiety based on the devised cascade reactivity were undertaken. Initial catalyst screening involving 4benzylidene-2-phenyloxazol-5-ones $\mathbf{2 a}$ as a model Michael acceptor was limited to cinchona alkaloid derivatives 10c and 10d (Table 2, entries 1,2) as these systems proved the best in the synthesis of tetrahydrothiophenes $\mathbf{9}$. It was found that also in this cascade dimeric catalyst 10d afforded spirocyclic product 8a (that was directly subjected to the acylation reaction to give 11a) with the highest stereochemical efficiency. Therefore, 10d was employed in the solvent screening (Table 2, entries 2-6) that enabled us to identify toluene as the best solvent (Table 2, entry 6). Subsequent temperature screening revealed that performing the reaction at temperatures below room temperature is obligatory (Table 2, entries 6-9). However, at this stage in the study it was found that the isolated yield of a product 11a over two steps was disappointingly low, despite the full conversion of $\mathbf{2 a}$ observed. As the highest isolated yield was obtained at $4{ }^{\circ} \mathrm{C}$ further optimization with regard to reaction concentration effect was performed at this temperature (Table 2, entries 6-10,11). It was found that the chemical efficiency increased with the concentration of the reaction mixture. The relative ratio of the reactants was the last optimized parameter (Table 2, entries 12, 13). Notably, these experiments were performed in a $0.5 \mathrm{M}$ solution in toluene as there were problems with the solubility of $\mathbf{2 a}$ under more concentrated conditions. As the highest yield was obtained using 2-fold excess of azlactone $2 \mathbf{a}$ (with respect to 2-mercaptoacetaldehyde 4), it was decided to perform the scope studies under these conditions (Table 2, entry 13).

Table 2. Asymmetric organocatalytic synthesis of tetrahydrothiophenes $\mathbf{1 1}$ bearing an azlactone scaffold - optimization studies ${ }^{\mathrm{a}}$

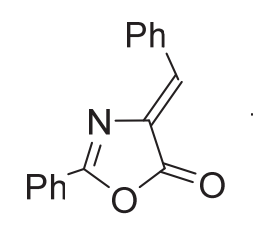

$2 a$<smiles>OC1CSC(O)CS1</smiles>

3

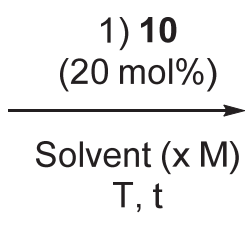

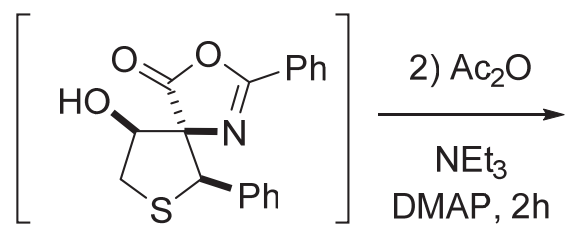

$8 a$

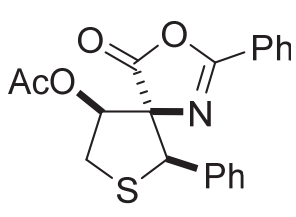

$11 a$ 
Table 2 (continued)

\begin{tabular}{ccccccccc}
\hline Entry & Catalyst & Solvent & $\begin{array}{c}\text { Time } \\
{[\text { days }]}\end{array}$ & $\begin{array}{c}\text { Concentration } \\
{[\mathrm{M}]}\end{array}$ & $\begin{array}{c}\text { Temperature } \\
{\left[{ }^{\circ} \mathrm{C}\right]}\end{array}$ & $\begin{array}{c}\text { Conversion } \\
{[\%]^{\mathrm{b}}}\end{array}$ & $\begin{array}{c}\mathrm{dr}^{\mathrm{c}} \\
\begin{array}{c}\text { ee } \\
{[\%]^{\mathrm{d}}}\end{array}\end{array}$ \\
\hline 1 & $\mathbf{1 0 c}$ & $\mathrm{THF}$ & 2 & 0.5 & 4 & $>95$ & $4: 1$ & 14 \\
2 & $\mathbf{1 0 d}$ & $\mathrm{THF}$ & 2 & 0.5 & 4 & $>95$ & $10: 1$ & 37 \\
3 & $\mathbf{1 0 d}$ & $\mathrm{CH}_{2} \mathrm{Cl} \mathrm{C}_{2}$ & 2 & 0.5 & 4 & $<5$ & n.d. & n.d. \\
4 & $\mathbf{1 0 d}$ & $\mathrm{CH}_{3} \mathrm{CN}$ & 2 & 0.5 & 4 & $<5$ & n.d. & n.d. \\
5 & $\mathbf{1 0 d}$ & Xylene & 5 & 0.5 & 4 & 67 & $4: 1$ & 79 \\
6 & $\mathbf{1 0 d}$ & Toluene & 2 & 0.5 & 4 & $>95(27)$ & $4: 1$ & 76 \\
7 & $\mathbf{1 0 d}$ & Toluene & 2 & 0.5 & 10 & $>95(<5)$ & $>20: 1$ & 80 \\
8 & $\mathbf{1 0 d}$ & Toluene & 7 & 0.5 & -15 & $40(10)$ & $4: 1$ & 57 \\
9 & $\mathbf{1 0 d}$ & Toluene & 10 & 0.5 & -40 & $<5$ & n.d. & n.d. \\
10 & $\mathbf{1 0 d}$ & Toluene & 2 & 1.00 & 4 & $>95(39)$ & $4: 1$ & 78 \\
11 & $\mathbf{1 0 d}$ & Toluene & 2 & 0.25 & 4 & $>95(19)$ & $4: 1$ & 80 \\
$12^{\mathrm{e}}$ & $\mathbf{1 0 d}$ & Toluene & 2 & 0.5 & 4 & $>95(24)$ & $3: 1$ & 60 \\
$13^{\mathrm{f}}$ & $\mathbf{1 0 d}$ & Toluene & 2 & 0.5 & 4 & $>95(44)$ & $3: 1$ & 72 \\
\hline
\end{tabular}

${ }^{\text {a }}$ Reactions performed on $0.1 \mathrm{mmol}$ scale using 2a (1 equiv) and 3 (1 equiv) in $0.2 \mathrm{~mL}$ of the solvent (see the Experimental Section for detailed reaction conditions). ${ }^{b}$ Determined by ${ }^{1} \mathrm{H}$ NMR of a crude reaction mixture. In parentheses the isolated yield over two step is given. ${ }^{\mathrm{c}}$ Determined by ${ }^{1} \mathrm{H}$ NMR of a crude reaction mixture. ${ }^{\mathrm{d}}$ Determined by a chiral stationary phase HPLC. Enantiomeric excesses reported for the major diastereoisomer. ${ }^{\mathrm{e}}$ Reaction performed using $\mathbf{2 a}$ ( 2 equiv) and $\mathbf{3}$ (1 equiv). ${ }^{\mathrm{f}}$ Reaction performed using $\mathbf{2 a}$ (4 equiv) and $\mathbf{3}$ (1 equiv).

Notwithstanding the moderate results obtained in the screening studies, the scope and limitations of the methodology was evaluated (Scheme 4). Various $\alpha, \beta$-unsaturated azlactones 2 bearing either electron-withdrawing or donating substituents on the aromatic ring of the alkylidene moiety were reacted with $\mathbf{3}$. Interestingly, tetrahydrothiophenes $\mathbf{1 1 b}, \mathbf{c}$ were obtained in a highly stereoselective fashion. Disappointingly, the reaction proceeded with low chemical efficiency when compared to the synthesis of the model product 11a. With regard to the position of substituents, the introduction of a substituent in the ortho-position had a negative influence on the cascade outcome (Scheme 4, compound 11e).

The relative configuration of the products was assigned on the basis of 2D NOE experiments (Scheme 5). A strong correlation signal was observed for the $\mathrm{H} 2$ and $\mathrm{H} 4$ protons of the tetrahydrothiophene ring in the NOESY spectrum of 9a indicating the cis relationship of these two protons. Furthermore, due to the lack of NOE interactions of the vinylic proton of the butenolide moiety with either $\mathrm{H} 2$ or $\mathrm{H} 4$ protons, the cis alignment of the carbonyl group of the 
butenolide ring with relation to the $\mathrm{H} 2$ and $\mathrm{H} 4$ protons is deduced. The relative configuration of all other products $\mathbf{9}$ and $\mathbf{1 1}$ was assigned by analogy. The absolute configuration of stereogenic centers in tetrahydrothiophenes $\mathbf{9}$ and $\mathbf{1 1}$ was not studied.
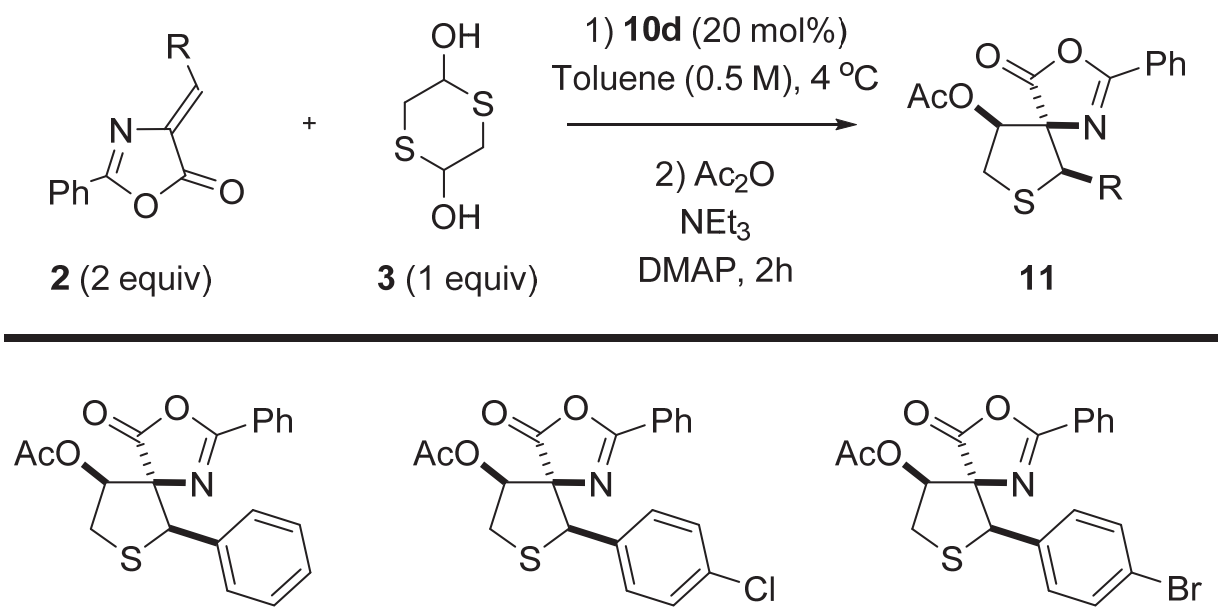

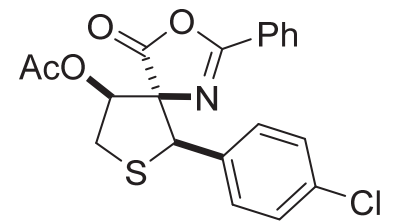

11b

$11 a$

$44 \%$ yield $3: 1 \mathrm{dr}$ $72 \%$ ee
$10 \%$ yield $>20: 1 \mathrm{dr}$ $82 \%$ ee<smiles>CC(=O)OC1CSC(c2ccc(Br)cc2)[C@@]12N=C(c1ccccc1)OC2=O</smiles>

11c

$9 \%$ yield $>20: 1 \mathrm{dr}$ $82 \%$ ee<smiles>CC(=O)OC1CSC(c2cccc(F)c2)C12N=C(c1ccccc1)OC2=O</smiles>

11d $30 \%$ yield 10:1 dr $55 \%$ ee

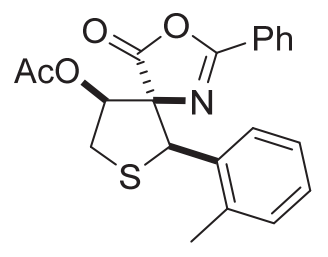

$11 e$ $34 \%$ yield

$2: 1 \mathrm{dr}$ $60 \%$ ee

Scheme 4. Asymmetric, organocatalytic synthesis of tetrahydrothiophenes $\mathbf{1 1}$ bearing an azlactone scaffold - scope studies.

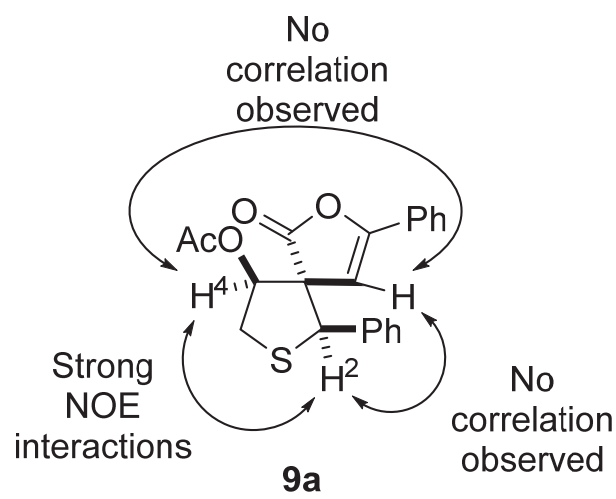

Scheme 5. Relative configuration assignments on the basis of NOESY experiment. 


\section{Conclusions}

In conclusion: we have developed a new method leading to spirocyclic tetrahydrothiophenes bearing either butenolide or azlactone structural motif. It was found that the reaction cascade consisting of a thio-Michael addition of 2-mercaptoacetaldehyde (generated in situ from 1,4dithiane-2,5-diol) with $\alpha, \beta$-unsaturated butenolides or azlactones followed by the intramolecular aldol reaction can be realized under basic catalytic conditions. Furthermore, the usage of a chiral Brønsted base ensures the reaction to proceed in the enantioselective fashion. Disappointingly, in some cases reactions proceeded with moderate or low stereoselectivity. The relative configuration of the products was assigned by $2 \mathrm{D} \mathrm{NOE}$ experiments.

\section{Experimental Section}

General. ${ }^{1} \mathrm{H}$ and ${ }^{13} \mathrm{C}$ NMR spectra were recorded on a Bruker Ultra Shield 700 instrument. ${ }^{1} \mathrm{H}$ NMR with the solvent reference relative to TMS employed as the internal standard $\left(\mathrm{CDCl}_{3}, \delta=\right.$ 7.26); ${ }^{13} \mathrm{C}$ NMR relative to TMS with the respective solvent resonance as the internal standard $\left(\mathrm{CDCl}_{3}, \delta=77.16\right)$. Mass spectra were recorded on a Bruker Maxis Impact spectrometer using electrospray (ES+) ionization. Flash chromatography was performed on Merck silica gel (60, particle size: $35-70 \mu \mathrm{m})$. TLC was carried out on commercially available pre-coated plates (Silica on TLC Alu foils, Fluka) and visualized by UV light. Optical rotations were measured on a Perkin-Elmer 241 polarimeter and $[\alpha]_{D}$ values are given in $\operatorname{deg} \cdot \mathrm{cm} \cdot \mathrm{g}^{-1} \cdot \mathrm{dm}^{-1}$; concentration $c$ is listed in $\mathrm{g} \cdot(100 \mathrm{~mL})^{-1}$. Enantiomeric excess of adduct was determined by chiral stationary phase HPLC using Daicel Chiralpak IA and IC column. $\alpha, \beta$-Unsaturated azlactones 1 and butenolides 2 were prepared according to literature procedures. ${ }^{47,48}$ Cinchona-alkaloid-derived catalysts $\mathbf{1 0 b}, \mathbf{c}$ were synthesized following the literature procedures. ${ }^{49,50}$ Commercially available catalysts and reagents were purchased from Aldrich and used as received.

\section{Enantioselective synthesis of spirocyclic tetrahydrothiophene derivatives 9 bearing a butenolide scaffold: general procedure}

An ordinary screw-cap vial was charged with a magnetic stirring bar, the corresponding butenolide $1(0.2 \mathrm{mmol})$, the 1,4-dithiane-2,5-diol $3(0.2 \mathrm{mmol})$, the catalyst $10 \mathrm{~d}(0.04 \mathrm{mmol})$ and xylene $(0.4 \mathrm{~mL})$. The reaction mixture was stirred at $10{ }^{\circ} \mathrm{C}$ and monitored by ${ }^{1} \mathrm{H}$ NMR spectroscopy. When the signals of starting material 1 were no longer observed, the crude reaction mixture was directly subjected to acetylation. $\mathrm{Ac}_{2} \mathrm{O}(14.2 \mu \mathrm{L}), \mathrm{Et}_{3} \mathrm{~N}(20 \mu \mathrm{L})$ and DMAP (catalytic amount) were added and the resulting mixture was stirred at $10{ }^{\circ} \mathrm{C}$ for $2 \mathrm{~h}$. The reaction mixture was then poured into saturated aqueous $\mathrm{NaHCO}_{3}(10 \mathrm{~mL})$, extracted with $\mathrm{CH}_{2} \mathrm{Cl}_{2}(3 \times$ $10 \mathrm{~mL}$ ), dried over $\mathrm{MgSO}_{4}$ and evaporated under reduced pressure. The residue obtained was directly purified by FC on silica gel (gradient hexane/AcOEt from 95:5 to 9:1) to afford target product 9. 
1-Oxo-3,6-diphenyl-2-oxa-7-thiaspiro[4.4]non-3-en-9-yl acetate (9a). Following the general procedure 9a was obtained as a yellow oil (55\% yield) after $72 \mathrm{~h}(\mathrm{dr}=5: 1)$. Major diastereoisomer: ${ }^{1} \mathrm{H}$ NMR $\left(700 \mathrm{MHz}, \mathrm{CDCl}_{3}\right)$ : $\delta 7.46-7.44(\mathrm{~m}, 2 \mathrm{H}), 7.39-7.37(\mathrm{~m}, 2 \mathrm{H}), 7.36-$ $7.32(\mathrm{~m}, 3 \mathrm{H}), 7.24-7.21(\mathrm{~m}, 2 \mathrm{H}), 7.20-7.17(\mathrm{~m}, 1 \mathrm{H}), 5.87(\mathrm{~s}, 1 \mathrm{H}), 5.64(\mathrm{dd}, J 8.8,7.3 \mathrm{~Hz}$, $1 \mathrm{H}), 5.00(\mathrm{~s}, 1 \mathrm{H}), 3.66(\mathrm{dd}, J 10.8,7.3 \mathrm{~Hz}, 1 \mathrm{H}), 3.07(\mathrm{dd}, J 10.8,8.8 \mathrm{~Hz}, 1 \mathrm{H}), 1.98(\mathrm{~s}, 3 \mathrm{H}) .{ }^{13} \mathrm{C}$ NMR (176 MHz, $\left.\mathrm{CDCl}_{3}\right): \delta 176.0,169.8,153.8,134.4,130.2,128.7,128.7$ (2C), 128.7 (2C), 128.5 (2C), 127.8, 125.2 (2C), 99.0, 79.7, 65.9, 54.8, 32.8, 20.8. HRMS calculated for $\left[\mathrm{C}_{21} \mathrm{H}_{18} \mathrm{O}_{4} \mathrm{~S}+\mathrm{H}\right]^{+}$: 367.0999 ; found: 367.1005 . The ee was determined by HPLC using a Chiralpak IA column [hexane $/ i-\mathrm{PrOH}(90: 10)]$; flow rate $1.0 \mathrm{~mL} / \mathrm{min} ; \tau_{\text {major }}=7.8 \mathrm{~min}, \tau_{\text {minor }}=$ $8.9 \min (70 \%$ ee $) ;[\alpha]_{\mathrm{D}}^{20}=-65.3\left(c=0.6, \mathrm{CHCl}_{3}\right)$. Representative signals for the minor diasteroisomer: ${ }^{1} \mathrm{H}$ NMR $\left(700 \mathrm{MHz}, \mathrm{CDCl}_{3}\right) \delta 5.70(\mathrm{dd}, J 5.2,3.5 \mathrm{~Hz}, 1 \mathrm{H}), 5.08(\mathrm{~s}, 1 \mathrm{H}), 3.57$ $(\mathrm{dd}, J 12.0,5.2 \mathrm{~Hz}, 1 \mathrm{H}), 3.30(\mathrm{dd}, J 12.0,3.5 \mathrm{~Hz}, 1 \mathrm{H}), 2.17$ (s, 3H). ${ }^{13} \mathrm{C} \mathrm{NMR}(176 \mathrm{MHz}$, $\mathrm{CDCl}_{3}$ ): $\delta 174.1,170.0,153.8,135.3,130.3,129.0$ (2C), 128.7 (2C), 128.6, 128.5 (2C), 127.6, $125.2(2 \mathrm{C}), 100.5,79.2,65.1,55.6,35.5,21.0$.

1-Oxo-3-phenyl-6-p-tolyl-2-oxa-7-thiaspiro[4.4]non-3-en-9-yl acetate (9b). Following the general procedure 9b was obtained as a yellow oil (38\% yield) after $72 \mathrm{~h}(\mathrm{dr}=5: 1)$. Major diastereoisomer: ${ }^{1} \mathrm{H}$ NMR $\left(700 \mathrm{MHz}, \mathrm{CDCl}_{3}\right): \delta 7.49-7.46(\mathrm{~m}, 2 \mathrm{H}), 7.37-7.34(\mathrm{~m}, 4 \mathrm{H}), 7.25$ (s, 1H), $7.03-7.01(\mathrm{~m}, 2 \mathrm{H}), 5.90(\mathrm{~s}, 1 \mathrm{H}), 5.62(\mathrm{dd}, J 8.8,7.3 \mathrm{~Hz}, 1 \mathrm{H}), 4.96(\mathrm{~s}, 1 \mathrm{H}), 3.64(\mathrm{dd}, J$ 10.8, 7.3 Hz, 1H), 3.06 (dd, $J 10.8,8.8 \mathrm{~Hz}, 1 \mathrm{H}), 2.23(\mathrm{~s}, 3 \mathrm{H}), 1.97$ (s, 3H). ${ }^{13} \mathrm{C}$ NMR $(176 \mathrm{MHz}$, $\left.\mathrm{CDCl}_{3}\right): \delta 176.0,169.9,153.7,138.6,131.3,130.1,129.2(2 \mathrm{C}), 128.8(2 \mathrm{C}), 128.7(2 \mathrm{C}), 127.9$, 125.3 (2C), 99.1, 79.8, 65.9, 54.5, 32.7, 21.2, 20.8. HRMS calculated for $\left[\mathrm{C}_{22} \mathrm{H}_{20} \mathrm{O}_{4} \mathrm{~S}+\mathrm{H}\right]^{+}$: 381.1155; found: 381.1150. The ee was determined by HPLC using a Chiralpak IA column [hexane $/ i$-PrOH (95:5)]; flow rate $1.0 \mathrm{~mL} / \mathrm{min} ; \tau_{\text {major }}=8.6 \mathrm{~min}, \tau_{\operatorname{minor}}=10.9 \mathrm{~min}(42 \%$ ee $) ;[\alpha]_{\mathrm{D}}^{20}$ $=-94.2\left(c=0.4, \mathrm{CHCl}_{3}\right)$. Representative signals for the minor diasteroisomer: ${ }^{1} \mathrm{H}$ NMR $(700$ $\left.\mathrm{MHz}, \mathrm{CDCl}_{3}\right) \delta 5.69(\mathrm{dd}, \mathrm{J} 5.2,3.5 \mathrm{~Hz}, 1 \mathrm{H}), 5.05$ (s, 1H), $3.56(\mathrm{dd}, J 12.0,5.2 \mathrm{~Hz}, 1 \mathrm{H}), 3.28$ (dd, $J$ 12.0, $3.5 \mathrm{~Hz}, 1 \mathrm{H}), 2.26(\mathrm{~s}, 3 \mathrm{H}), 2.16(\mathrm{~s}, 3 \mathrm{H}) .{ }^{13} \mathrm{C} \mathrm{NMR}\left(176 \mathrm{MHz}, \mathrm{CDCl}_{3}\right): \delta$ 174.2, 170.1, $153.7,138.4,132.2,130.3,129.3$ (2C), 129.0 (2C), 128.8 (2C),127.7, 125.3 (2C), 100.7, 79.3, $66.2,55.3,35.3,21.3,21.0$.

1-Oxo-3-phenyl-6-(4-(trifluoromethyl)phenyl)-2-oxa-7-thiaspiro[4.4]non-3-en-9-yl acetate (9c). Following the general procedure 9c was obtained as a yellow oil (35\% yield) after $48 \mathrm{~h}(\mathrm{dr}$ $>20: 1$ ). Major diastereoisomer: ${ }^{1} \mathrm{H}$ NMR (250 MHz, Chloroform-d): $\delta 7.51$ (s, 4H), $7.49-7.43$ $(\mathrm{m}, 2 \mathrm{H}), 7.40-7.33(\mathrm{~m}, 3 \mathrm{H}), 5.83(\mathrm{~s}, 1 \mathrm{H}), 5.63(\mathrm{dd}, J$ 8.4, $4.6 \mathrm{~Hz}, 1 \mathrm{H}), 5.02(\mathrm{~s}, 1 \mathrm{H}), 3.69-3.62$ $(\mathrm{m}, 1 \mathrm{H}), 3.15-3.08(\mathrm{~m}, 1 \mathrm{H}), 1.98(\mathrm{~s}, 3 \mathrm{H}) .{ }^{13} \mathrm{C} \mathrm{NMR}\left(176 \mathrm{MHz}, \mathrm{CDCl}_{3}\right): \delta 175.2,169.8,162.7$, 154.1, 137.3, 130.3, 128.6 (q, J 31.9 Hz, 2C), 127.9, 127.1 (2C), 125.3 (2C), 124.9 (q, J 3.7 Hz, 2C), $124.1(\mathrm{q}, J 270.3 \mathrm{~Hz}), 97.6,79.7,64.8,52.1,31.9,21.7$. HRMS calculated for $\left[\mathrm{C}_{22} \mathrm{H}_{17} \mathrm{~F}_{3} \mathrm{O}_{4} \mathrm{~S}+\mathrm{H}\right]^{+}:$435.0872; found: 435.0861. The ee was determined by HPLC using a Chiralpak IA column [hexane $/ i$-PrOH (95:5)]; flow rate $1.0 \mathrm{~mL} / \mathrm{min} ; \tau_{\text {major }}=9.0 \mathrm{~min}, \tau_{\text {minor }}=$ $12.8 \min (32 \%$ ee $) ;[\alpha]_{\mathrm{D}}^{20}=-53.7\left(c=0.3, \mathrm{CHCl}_{3}\right)$.

6-(3-Fluorophenyl)-1-oxo-3-phenyl-2-oxa-7-thiaspiro[4.4]non-3-en-9-yl acetate (9d). Following the general procedure 9d was obtained as a yellow oil (52\% yield) after $72 \mathrm{~h}(\mathrm{dr}=$ 
9:1). Major diastereoisomer: ${ }^{1} \mathrm{H} \mathrm{NMR}\left(700 \mathrm{MHz}, \mathrm{CDCl}_{3}\right): \delta 7.48-7.45(\mathrm{~m}, 2 \mathrm{H}), 7.38-7.34(\mathrm{~m}$, $3 \mathrm{H}), 7.21-7.16(\mathrm{~m}, 2 \mathrm{H}), 7.12-7.10(\mathrm{~m}, 1 \mathrm{H}), 6.89$ (tdd, $J 8.4,2.5,1.0 \mathrm{~Hz}, 1 \mathrm{H}), 5.83(\mathrm{~s}, 1 \mathrm{H})$, $5.62(\mathrm{dd}, J 8.8,7.3 \mathrm{~Hz}, 1 \mathrm{H}), 4.97(\mathrm{~s}, 1 \mathrm{H}), 3.65(\mathrm{dd}, J 10.8,7.3 \mathrm{~Hz}, 1 \mathrm{H}), 3.08$ (dd, $J 10.8,8.8 \mathrm{~Hz}$, 1H), $1,98(\mathrm{~s}, 3 \mathrm{H}) .{ }^{13} \mathrm{C} \mathrm{NMR}\left(176 \mathrm{MHz}, \mathrm{CDCl}_{3}\right): \delta 175.8,169.8,162.7$ (d, $\left.J 246.7 \mathrm{~Hz}\right), 154.1$, $137.3(\mathrm{~d}, J 7.3 \mathrm{~Hz}), 130.3,130.1$ (d, J 8.3 Hz), $128.8(2 \mathrm{C}), 127.6,125.3(2 \mathrm{C}), 124.5,115.8$ (d, $J$ $21.4 \mathrm{~Hz}), 115.7(\mathrm{~d}, J 22.6 \mathrm{~Hz}), 98.6,79.6,65.8,54.1,32.9,20.7$. HRMS calculated for $\left[\mathrm{C}_{21} \mathrm{H}_{17} \mathrm{FO}_{4} \mathrm{~S}+\mathrm{H}\right]^{+}:$385.0904; found: 385.0901. The ee was determined by HPLC using a Chiralpak IA column [hexane $/ i$-PrOH (95:5)]; flow rate $1.0 \mathrm{~mL} / \mathrm{min} ; \tau_{\text {major }}=10.1 \mathrm{~min}, \tau_{\text {minor }}=$ $12.3 \min (58 \%$ ee $) .[\alpha]_{\mathrm{D}}^{20}=-155.6\left(c=0.5, \mathrm{CHCl}_{3}\right)$. Representative signals for the minor diasteroisomer: ${ }^{1} \mathrm{H}$ NMR $\left(700 \mathrm{MHz}, \mathrm{CDCl}_{3}\right) \delta 5.69(\mathrm{dd}, J$ 5.0, $3.2 \mathrm{~Hz}, 1 \mathrm{H}), 5.08(\mathrm{~s}, 1 \mathrm{H}), 3.58$ $(\mathrm{dd}, J 12.1,5.1 \mathrm{~Hz}, 1 \mathrm{H}), 2.12(\mathrm{~s}, 3 \mathrm{H}) .{ }^{13} \mathrm{C} \mathrm{NMR}\left(176 \mathrm{MHz}, \mathrm{CDCl}_{3}\right): \delta 169.8,138.0(\mathrm{~d}, J 7.1 \mathrm{~Hz})$, 130.5, 128.8 (2C), 127.4, 125.3 (2C), 124.8 (d, J 2.8 Hz), 100.0, 79.3, 65.1, 55.1, 35.6, 21.0.

6-(2-Fluorophenyl)-1-oxo-3-phenyl-2-oxa-7-thiaspiro[4-4]non-3-en-9-yl acetate (9e). Following the general procedure 9e was obtained as a yellow oil $(40 \%$ yield $)$ after $72 \mathrm{~h}(\mathrm{dr}=$ 5:1). Major diastereoisomer: ${ }^{1} \mathrm{H}$ NMR $\left(250 \mathrm{MHz}, \mathrm{CDCl}_{3}\right): \delta 7.53-7.48(\mathrm{~m}, 4 \mathrm{H}), 7.47-7.43(\mathrm{~m}$, 2H), $7.37-7.34(\mathrm{~m}, 2 \mathrm{H}), 5.92(\mathrm{dd}, J 8.4,4.6 \mathrm{~Hz}, 1 \mathrm{H}), 5.83(\mathrm{~s}, 1 \mathrm{H}), 5.68-5.58(\mathrm{~m}, 1 \mathrm{H}), 5.02(\mathrm{~s}$, $1 \mathrm{H}), 3.69-3.62(\mathrm{~m}, 1 \mathrm{H}), 3.15-3.08(\mathrm{~m}, 1 \mathrm{H}), 1.98(\mathrm{~s}, 3 \mathrm{H}) .{ }^{13} \mathrm{C} \mathrm{NMR}\left(176 \mathrm{MHz}, \mathrm{CDCl}_{3}\right): \delta$ 175.7, 169.6, 160.6 (d, J 248.3 Hz), 153.9, 132.1 (d, J 9.9 Hz), 130.8 (d, J 3.2 Hz), 130.1, 128.6 (2C), 127.7, 125.1 (2C) , 123.8 (d, J 3.6 Hz), 122.5 (d, J $12.5 \mathrm{~Hz}), 115.5$ (d, J 22.1 Hz), 98.3, 79.7, 66.2, 54.1, 32.9, 20.7. HRMS calculated for $\left[\mathrm{C}_{21} \mathrm{H}_{17} \mathrm{FO}_{4} \mathrm{~S}+\mathrm{H}\right]^{+}: 385.0904$; found: 385.0915. The ee was determined by HPLC using a Chiralpak IA column [hexane/i-PrOH (95:5)]; flow rate $1.0 \mathrm{~mL} / \mathrm{min} ; \tau_{\text {major }}=12.8 \mathrm{~min}, \tau_{\text {minor }}=14.7 \mathrm{~min}(21 \%$ ee $) .[\alpha]_{\mathrm{D}}^{20}=-86.7\left(c=0.5, \mathrm{CHCl}_{3}\right)$. Representative signals for the minor diasteroisomer: ${ }^{1} \mathrm{H} \mathrm{NMR}\left(700 \mathrm{MHz}, \mathrm{CDCl}_{3}\right) 5.70(\mathrm{dd}, J$ 5.0, $3.1 \mathrm{~Hz}, 1 \mathrm{H}), 5.13(\mathrm{~s}, 1 \mathrm{H}), 5.08(\mathrm{~s}, 1 \mathrm{H}), 2.08(\mathrm{~s}, 1 \mathrm{H})$.

Enantioselective synthesis of spirocyclic tetrahydrothiophene derivatives bearing an azlactone scaffold. General procedure. An ordinary screw-cap vial was charged with a magnetic stirring bar, the corresponding azlactone $2(0.4 \mathrm{mmol})$, the 1,4-dithiane-2,5-diol $3(0.1$ $\mathrm{mmol})$, the catalyst $10 \mathrm{~d}(0.02 \mathrm{mmol})$ and toluene $(0.2 \mathrm{~mL})$. The reaction mixture was stirred at 4 ${ }^{\circ} \mathrm{C}$ and monitored by ${ }^{1} \mathrm{H}$ NMR spectroscopy. When the signals of a starting material 2 were no longer observed, the crude reaction mixture was directly subjected to acetylation. $\mathrm{Ac}_{2} \mathrm{O}(28.4$ $\mu \mathrm{L}), \mathrm{Et}_{3} \mathrm{~N}(40 \mu \mathrm{L})$ and DMAP (catalytic amount) were added and the resulting solution was stirred at $4^{\circ} \mathrm{C}$ for $2 \mathrm{~h}$. The reaction mixture was poured into saturated aqueous $\mathrm{NaHCO}_{3}$ solution $(10 \mathrm{~mL})$, extracted with $\mathrm{CH}_{2} \mathrm{Cl}_{2}(3 \times 10 \mathrm{~mL})$, dried over $\mathrm{MgSO}_{4}$ and evaporated under reduced pressure. The residue obtained was directly purified by FC on silica gel (gradient hexane/AcOEt from 95:5 to 9:1) to afford a target product 11.

4-Oxo-2,6-diphenyl-3-oxa-7-thia-1-azaspiro[4.4]non-1-en-9-yl acetate (11a). Following the general procedure 11a was obtained as a yellow oil (44\% yield) after $48 \mathrm{~h}(\mathrm{dr}=3: 1)$. Major diastereoisomer: ${ }^{1} \mathrm{H}$ NMR $\left(700 \mathrm{MHz}, \mathrm{CDCl}_{3}\right)$ : $7.90-7.87(\mathrm{~m}, 2 \mathrm{H}), 7.56-7.52(\mathrm{~m}, 1 \mathrm{H}), 7.46-$ $7.40(\mathrm{~m}, 4 \mathrm{H}), 7.21-7.14(\mathrm{~m}, 3 \mathrm{H}), 5.69(\mathrm{dd}, J 9.8,7.0 \mathrm{~Hz}, 1 \mathrm{H}), 5.03$ (s, 1H), 3.58 (dd, J 9.8, 7.0 
$\mathrm{Hz}, 1 \mathrm{H}), 3.48(\mathrm{t}, J 9.8 \mathrm{~Hz}, 1 \mathrm{H}), 1.96(\mathrm{~s}, 3 \mathrm{H}) .{ }^{13} \mathrm{C} \mathrm{NMR}\left(176 \mathrm{MHz}, \mathrm{CDCl}_{3}\right): \delta 175.8,169.8,161.5$, 133.6, 133.4, 133.1, 129.7 (2C), 128.8 (2C), 128.3 (2C), 128.2 (2C), 125.3, 80.7, 78.9, 54.0, 32.5, 20.7. HRMS calculated for $\left[\mathrm{C}_{20} \mathrm{H}_{17} \mathrm{NO}_{4} \mathrm{~S}+\mathrm{H}\right]^{+}: 368.0951$; found: 368.0958 . The ee was determined by HPLC using a Chiralpak IA column [hexane/i-PrOH (90:10)]; flow rate 1.0 $\mathrm{mL} / \mathrm{min} ; \tau_{\text {major }}=6.3 \mathrm{~min}, \tau_{\text {minor }}=6.8 \min (72 \%$ ee $) ;[\alpha]_{\mathrm{D}}^{20}=-96.2\left(c=0.6, \mathrm{CHCl}_{3}\right)$.

Representative signals for the minor diasteroisomer: ${ }^{1} \mathrm{H} \mathrm{NMR}\left(700 \mathrm{MHz}, \mathrm{CDCl}_{3}\right) \delta 5.74(\mathrm{dd}, J$ 10.0, $7.3 \mathrm{~Hz}, 1 \mathrm{H}), 5.04(\mathrm{~s}, 1 \mathrm{H}), 1.97(\mathrm{~s}, 3 \mathrm{H}) .{ }^{13} \mathrm{C} \mathrm{NMR}\left(176 \mathrm{MHz}, \mathrm{CDCl}_{3}\right): \delta 172.4,169.6,162.8$, 133.6, 133.3, 133.1, 129.7 (2C), 128.9 (2C), 128.6 (2C) , 128.3 (2C), 125.3, 81.8, 77.9, 50.9, $32.5,20.8$.

6-(4-Chlorophenyl)-4-oxo-2-phenyl-3-oxa-7-thia-1-azaspiro[4.4]non-1-en-9-yl acetate (11b). Following the general procedure 11b was obtained as a yellow oil (10\% yield) after $96 \mathrm{~h}(\mathrm{dr}$ >20:1). Major diastereoisomer: ${ }^{1} \mathrm{H}$ NMR (700 MHz, $\left.\mathrm{CDCl}_{3}\right): \delta 7.90$ (dd, J 8.3, $\left.1.3 \mathrm{~Hz}, 2 \mathrm{H}\right), 7.59$ - $7.56(\mathrm{~m}, 1 \mathrm{H}), 7.48-7.43(\mathrm{~m}, 2 \mathrm{H}), 7.40-7.38(\mathrm{~m}, 2 \mathrm{H}), 7.18-7.15(\mathrm{~m}, 2 \mathrm{H}), 5.66(\mathrm{dd}, J 9.8$, $7.0 \mathrm{~Hz}, 1 \mathrm{H}), 4.99(\mathrm{~s}, 1 \mathrm{H}), 3.57(\mathrm{dd}, J 9.8,7.0 \mathrm{~Hz}, 1 \mathrm{H}), 3.48(\mathrm{t}, J 9.9 \mathrm{~Hz}, 1 \mathrm{H}), 1.96(\mathrm{~s}, 3 \mathrm{H}) .{ }^{13} \mathrm{C}$ NMR (176 MHz, $\left.\mathrm{CDCl}_{3}\right): \delta 175.6,169.7,161.8,134.8,133.4,132.2,131.1$ (2C), 128.9 (2C), 128.5 (2C), 128.3 (2C), 125.1, 80.5, 78.9, 53.2, 32.5, 20.7. HRMS calculated for $\left[\mathrm{C}_{20} \mathrm{H}_{16} \mathrm{ClNO}_{4} \mathrm{~S}+\mathrm{H}\right]^{+}:$402.0561; found: 402.0569. The ee was determined by HPLC using a Chiralpak IC column [hexane $/ i-\mathrm{PrOH}(95: 5)]$; flow rate $1.0 \mathrm{~mL} / \mathrm{min} ; \tau_{\text {major }}=10.0 \mathrm{~min}, \tau_{\text {minor }}=$ $9.3 \min (82 \%$ ee $) ;[\alpha]_{\mathrm{D}}^{20}=-62.7\left(c=0.4, \mathrm{CHCl}_{3}\right)$.

6-(4-Bromophenyl)-4-oxo-2-phenyl-3-oxa-7-thia-1-azaspiro[4.4]non-1-en-9-yl acetate (11c). Following the general procedure 11c was obtained as a yellow oil (9\% yield) after $96 \mathrm{~h}(\mathrm{dr}$ $>20: 1)$. Major diastereoisomer: ${ }^{1} \mathrm{H} \mathrm{NMR}\left(700 \mathrm{MHz}, \mathrm{CDCl}_{3}\right) \delta 7.93-7.88(\mathrm{~m}, 2 \mathrm{H}), 7.59-7.55$ $(\mathrm{m}, 1 \mathrm{H}), 7.48-7.43(\mathrm{~m}, 2 \mathrm{H}), 7.33(\mathrm{~d}, J 1.7 \mathrm{~Hz}, 4 \mathrm{H}), 5.66(\mathrm{dd}, J$ 9.8, $7.0 \mathrm{~Hz}, 1 \mathrm{H}), 4.97(\mathrm{~s}, 1 \mathrm{H})$, $3.57(\mathrm{dd}, J 9.8,7.0 \mathrm{~Hz}, 1 \mathrm{H}), 3.48(\mathrm{t}, J 9.9 \mathrm{~Hz}, 1 \mathrm{H}), 1.96(\mathrm{~s}, 3 \mathrm{H}) .{ }^{13} \mathrm{C} \mathrm{NMR}\left(176 \mathrm{MHz}, \mathrm{CDCl}_{3}\right) \delta$ $175.5,169.7,161.8,133.8,133.4,132.7,131.5$ (2C), $131.4(2 \mathrm{C}), 128.9$ (2C), 128.3 (2C), 125.1, 80.4, 78.9, 53.2, 31.7, 22.8. HRMS calculated for $\left[\mathrm{C}_{20} \mathrm{H}_{16} \mathrm{BrNO}_{4} \mathrm{~S}+\mathrm{H}\right]^{+}:$446.0056; found: 446.0044. The ee was determined by HPLC using a Chiralpak IC column [hexane $i-\mathrm{PrOH}$ $(95: 5)]$; flow rate $1.0 \mathrm{~mL} / \mathrm{min} ; \tau_{\text {major }}=10.5 \mathrm{~min}, \tau_{\text {minor }}=9.5 \mathrm{~min}(82 \%$ ee $) ;[\alpha]_{\mathrm{D}}^{20}=-35.8(c=0.4$, $\left.\mathrm{CHCl}_{3}\right)$.

2-(3-Fluorophenyl)-4-oxo-6-phenyl-3-oxa-7-thia-1-azaspiro[4.4]non-1-en-9-yl acetate (11d). Following the general procedure 11d was obtained as a yellow oil $30 \%$ yield) after $72 \mathrm{~h}(\mathrm{dr}=$ 10:1). Major diastereoisomer: ${ }^{1} \mathrm{H}$ NMR $\left(250 \mathrm{MHz}, \mathrm{CDCl}_{3}\right): \delta 7.50-7.43(\mathrm{~m}, 2 \mathrm{H}), 7.39-7.32$ $(\mathrm{m}, 3 \mathrm{H}), 7.21-7.06(\mathrm{~m}, 3 \mathrm{H}), 6.99-6.86(\mathrm{~m}, 1 \mathrm{H}), 5.63(\mathrm{dd}, J$ 8.2, $6.6 \mathrm{~Hz}, 1 \mathrm{H}), 5.34(\mathrm{~s}, 1 \mathrm{H})$, $3.57(\mathrm{dd}, J 9.8,7.0 \mathrm{~Hz}, 1 \mathrm{H}), 3.48(\mathrm{t}, J 9.9 \mathrm{~Hz}, 1 \mathrm{H}), 1.99(\mathrm{~s}, 3 \mathrm{H}) .{ }^{13} \mathrm{C} \mathrm{NMR}\left(176 \mathrm{MHz}, \mathrm{CDCl}_{3}\right): \delta$ 175.6, 169.8, 162.5 (d, J 246.9 Hz), 161.7, 136.3 (d, J 7.5 Hz), 133.4, 129.8 (d, J 8.2 Hz), 128.9 (2C), 128.3 (2C), 125.2, 125.1 (d, J $2.9 \mathrm{~Hz}), 116.9$ (d, J 22.9 Hz), 116.0 (d, J 21.3 Hz), 80.5, 78.8, 53.3, 32.5, 20.7. HRMS calculated for $\left[\mathrm{C}_{20} \mathrm{H}_{16} \mathrm{FNO}_{4} \mathrm{~S}+\mathrm{H}\right]^{+}$: 386.0857; found: 386.0867 . The ee was determined by HPLC using a Chiralpak IC column [hexane/ $i$-PrOH (95:5)]; flow rate $1.0 \mathrm{~mL} / \mathrm{min} ; \tau_{\text {major }}=15.1 \mathrm{~min}, \tau_{\text {minor }}=12.2 \min (55 \%$ ee $) .[\alpha]_{\mathrm{D}}^{20}=-75.7\left(c=0.7, \mathrm{CHCl}_{3}\right)$. 
Representative signals for the minor diasteroisomer: ${ }^{1} \mathrm{H} \mathrm{NMR}\left(700 \mathrm{MHz}, \mathrm{CDCl}_{3}\right) 5.30(\mathrm{~s}, 1 \mathrm{H})$, 2.08 (s. 3H).

4-Oxo-2-phenyl-6-o-tolyl-3-oxa-7-thia-1-azaspiro[4.4]non-1-en-9-yl acetate (11e). Following the general procedure 11e was obtained as a yellow oil (34\% yield) after $48 \mathrm{~h}(\mathrm{dr}=2: 1)$. Major diastereoisomer: ${ }^{1} \mathrm{H}$ NMR $\left(700 \mathrm{MHz}, \mathrm{CDCl}_{3}\right) \delta 7.95-7.93(\mathrm{~m}, 2 \mathrm{H}), 7.88-7.85(\mathrm{~m}, 1 \mathrm{H}), 7.47-$ $7.43(\mathrm{~m}, 3 \mathrm{H}), 7.06-7.00(\mathrm{~m}, 3 \mathrm{H}), 5.73(\mathrm{dd}, J 9.8,7.0 \mathrm{~Hz}, 1 \mathrm{H}), 5.49$ (s, 1H), 3.59 (dd, J 9.8, 7.0 $\mathrm{Hz}, 1 \mathrm{H}), 3.51(\mathrm{t}, J 9.8 \mathrm{~Hz}, 1 \mathrm{H}), 2.34(\mathrm{~s}, 3 \mathrm{H}), 1.97(\mathrm{~s}, 3 \mathrm{H}) .{ }^{13} \mathrm{C} \mathrm{NMR}\left(176 \mathrm{MHz}, \mathrm{CDCl}_{3}\right)$ $\delta 176.2,169.8,161.4,137.0,133.2,131.9,130.4,129.4,128.9$ (2C), $128.4(2 \mathrm{C}), 128.2,126.6$, 125.5, 79.9, 79.3, 48.0, 32.5, 20.7, 19.7. HRMS calculated for $\left[\mathrm{C}_{21} \mathrm{H}_{19} \mathrm{NO}_{4} \mathrm{~S}+\mathrm{H}\right]^{+}: 382.1108$; found: 382.1106 . The ee was determined by HPLC using a Chiralpak IC column $[$ hexane $i-\mathrm{PrOH}$ (95:5)]; flow rate $1.0 \mathrm{~mL} / \mathrm{min} ; \tau_{\text {major }}=6.4 \mathrm{~min}, \tau_{\text {minor }}=6.8 \mathrm{~min}(60 \% \mathrm{ee}) ;[\alpha]_{\mathrm{D}}^{20}=-181.2(c=0.7$, $\left.\mathrm{CHCl}_{3}\right)$. Representative signals for the minor diasteroisomer: ${ }^{1} \mathrm{H} \mathrm{NMR}\left(700 \mathrm{MHz}, \mathrm{CDCl}_{3}\right) \delta 5.77$ (dd, J 9.9, 7.4 Hz, 1H), $5.46(\mathrm{~s}, 1 \mathrm{H}), 3.67(\mathrm{t}, J 10.0 \mathrm{~Hz}, 1 \mathrm{H}), 2.35(\mathrm{~s}, 3 \mathrm{H}), 1.96(\mathrm{~s}, 3 \mathrm{H}) .{ }^{13} \mathrm{C} \mathrm{NMR}$ $\left(176 \mathrm{MHz}, \mathrm{CDCl}_{3}\right): \delta 176.2,169.6,162.4,137.7,133.3,131.6,130.5,129.0(2 \mathrm{C}), 128.6,128.2$ (2C), 125.4, 82.7, 78.1, 46.4, 29.8, 20.8, 20.0.

\section{Acknowledgements}

The research was realized within the Lider programme from the National Center for Research and Development, Poland (NCBR, grant number LIDER/01/87/L-3/11/NCBR/2012). Dominika Lubelska is acknowledged for initial contributions.

\section{References}

1. Modern Drug Synthesis, John Wiley \& Sons, Inc, Hoboken, New Jersey, 2010.

2. Schreiber, S. L. Science 2000, 287, 1964. http://dx.doi.org/10.1126/science.287.5460.1964

3. Jacobsen, E. N.; Pfaltz, A.; Yamamoto, H. Comprehensive Asymmetric Catalysis, Springer, Berlin, 1999. http://dx.doi.org/10.1007/978-3-642-58571-5

4. Mikami, K.; Lautens, M. New Frontiers in Asymmetric Catalysis, Wiley-Interscience, New Jersey, 2007. http://dx.doi.org/10.1002/0470098007

5. List, B. Chem. Commun. 2006, 819. http://dx.doi.org/10.1039/b514296m

6. Erkkilä, A.; Majander, I.; Pihko, P. M. Chem. Rev. 2007, 107, 5416. http://dx.doi.org/10.1021/cr068388p

7. Enders, D.; Niemeier, O.; Henseler, A. Chem. Rev. 2007, 107, 5606. 
http://dx.doi.org/10.1021/cr068372z

8. Mukherjee, S.; Yang, J.-W.; Hoffmann, S.; List, B. Chem. Rev. 2007, 107, 5471. http://dx.doi.org/10.1021/cr0684016

9. Melchiorre, P.; Marigo, M.; Carlone, A.; Bartoli, G. Angew. Chem. Int. Ed. 2008, 47, 6138. http://dx.doi.org/10.1002/anie.200705523

10. Benetti, S.; De Risi, C.; Pollini, G. P.; Zanirato, V. Chem. Rev. 2012, 112, 2129. http://dx.doi.org/10.1021/cr200298b

11. Nudelman, A. The Chemistry of Optically Active Sulfur Compounds; Gordon and Breach: New York, 1984.

12. Damani, L. A. In Sulfur-containing drugs and related organic compounds: Chemistry, biochemistry, and toxicology; Ellis Horwood Ltd.: Chichester, U.K., 1989; Vol. 1, Part B.

13. Rao, Y. S. Chem. Rev. 1964, 64, 353. http://dx.doi.org/10.1021/cr60230a002

14. Rao, Y. S. Chem. Rev. 1976, 76, 625. http://dx.doi.org/10.1021/cr60303a004

15. Hashem, A.; Senning, A. Adv. Heterocycl. Chem. 1999, 73, 275. http://dx.doi.org/10.1016/S0065-2725(08)60944-7

16. Hashem, A.; Kleinpeter, E. Adv. Heterocycl. Chem. 2001, 81, 107. http://dx.doi.org/10.1016/S0065-2725(01)81011-4

17. Ospina, C. A.; Rodríguez, A. D. Org. Lett. 2009, 11, 3786. http://dx.doi.org/10.1021/o1901577a

18. Yu, Z.-G.; Li, J.; Li, Z.-Y.; Guo, Y.-W. Chem. Biodiversity 2009, 6, 858. http://dx.doi.org/10.1002/cbdv.200800108

19. Cativiela, C.; Diaz-de-Villegas, M. D. Tetrahedron: Asymmetry 2000, 11, 645. http://dx.doi.org/10.1016/S0957-4166(99)00565-0

20. Vogt, H.; Bräse, S. Org. Biomol. Chem. 2007, 5, 406. http://dx.doi.org/10.1039/B611091F

21. Doyle, A. G.; Jacobsen, E. N. Chem. Rev. 2007, 107, 5713. http://dx.doi.org/10.1021/cr068373r

22. Cativiela, C.; Diaz-de-Villegas, M. D. Tetrahedron: Asymmetry 2007, 18, 569. http://dx.doi.org/10.1016/j.tetasy.2007.02.003

23. Ohfune, Y.; Shinada, T. Eur. J. Org. Chem. 2005, 5127. http://dx.doi.org/10.1002/ejoc.200500434

24. Najera, C. Synlett 2002, 1388. http://dx.doi.org/10.1055/s-2002-33552

25. Alba, A-N. R.; Rios, R. Chem. Asian. J. 2011, 6, 720. http://dx.doi.org/10.1002/asia.201000636

26. Cabrera, S.; Reyes, E.; Alemán, J.; Milelli, A.; Kobbelgaard, S.; Jørgensen, K. A. J. Am. Chem. Soc. 2008, 130, 12031. http://dx.doi.org/10.1021/ja804567h 
27. Balaguer, A. N.; Companyó, X.; Calvet, T.; Font-Bardia, M.; Moyano, A.; Rios, R. Eur. J. Org. Chem. 2009, 199. http://dx.doi.org/10.1002/ejoc.200801005

28. Alba, A.-N. R.; Companyó, X.; Valero, G.; Moyano, A.; Rios, R. Chem. Eur. J. 2010, 16, 5354.

http://dx.doi.org/10.1002/chem.200903025

29. Jiang, H.; Gschwend, B.; Albrecht, Ł.; Hansen, S. G.; Jørgensen, K. A. Chem. Eur. J. 2011, $17,9032$.

http://dx.doi.org/10.1002/chem.201101539

30. Zhou, M.-Q.; Zuo, J.; Cui, B.-D.; Zhao, J.-Q.; You, Y.; Bai, M.; Chen, Y.-Z.; Zhang, X.-M.; Yuan, W.-C. Tetrahedron 2014, 70, 5787.

http://dx.doi.org/10.1016/j.tet.2014.06.042

31. Hejmanowska, J.; Dzięgielewski, M.; Kowalczyk, D.; Albrecht, Ł. Synthesis 2014, 46, 3233. http://dx.doi.org/10.1055/s-0034-1378997

32. Brandau, S.; Maerten, E.; Jørgensen, K. A. J. Am. Chem. Soc. 2006, 128, 14986. http://dx.doi.org/10.1021/ja065507+

33. Ling, J.-B.; Su, Y.; Zhu, H.-L.; Wang, G.-Y.; Xu, P.-F. Org. Lett. 2012, 14, 1090. http://dx.doi.org/10.1021/o12034959

34. Su, Y.; Ling, J.-B.; Zhang, S.; Xu, P.-F. J. Org. Chem. 2013, 78, 11053. http://dx.doi.org/10.1021/jo4016024

35. Zhao, B.; Liu, L.; Du, D. Eur. J. Org. Chem. 2014, 7850. http://dx.doi.org/10.1002/ejoc.201402889

36. Liang, J.-J.; Pan, J.-Y.; Xu, D.-C.; Xie, J.-W. Tetrahedron Lett. 2014, 55, 6335. http://dx.doi.org/10.1016/j.tetlet.2014.09.101

37. Marcelli, T.; van Maarseveen, J. H.; Hiemstra, H. Angew. Chem. Int. Ed. 2006, 45, 7496. http://dx.doi.org/10.1002/anie.200602318

38. Connon, S. J. Chem. Commun. 2008, 2499.

39. Jew, S.-S.; Park, H.-G. Chem. Commun. 2009, 7090. http://dx.doi.org/10.1039/b914028j

40. Palomo, C.; Oiarbide, M.; López R. Chem. Soc. Rev. 2009, 38, 632. http://dx.doi.org/10.1039/B708453F

41. Quigley, C.; Rodríguez-Docampo, Z.; Connon, S. J. Chem. Commun. 2012, 48, 1443. http://dx.doi.org/10.1039/c1cc14684j

42. Krawczyk, H.; Dzięgielewski, M.; Deredas, D.; Albrecht, A.; Albrecht, Ł. Chem. Eur. J. 2015, 21, 10268. http://dx.doi.org/10.1002/chem.201500481

43. Enders, D.; Grondahl, C.; Hüttl, M. R. M. Angew. Chem. Int. Ed. 2007, 46, 1570. http://dx.doi.org/10.1002/anie.200603129

44. Yu, X.; Wang, W. Org. Biomol. Chem. 2008, 6, 2037. http://dx.doi.org/10.1039/b800245m 
45. Grondal, C.; Jeanty, M.; Enders, D. Nat. Chem. 2010, 2, 167. http://dx.doi.org/10.1038/nchem.539

46. Wende, R. C.; Schreiner, P. R. Green Chem. 2012, 14, 1821. http://dx.doi.org/10.1039/c2gc35160a

47. El-Mekabaty, A. Int. J. Modern Org. Chem. 2013, 2, 40.

48. Wermuth, C. G.; Schlewer, G.; Bourguignon, J. J.; Maghioros, G.; Bouchet, M. J.; Moire, C.; Kan, J. P.; Worms, P.; Biziere, K. J. Med. Chem. 1989, 32, 528. http://dx.doi.org/10.1021/jm00123a004

49. Yang W.; Du D.-M. Org. Lett. 2010, 12, 5450. http://dx.doi.org/10.1021/o1102294g

50. Vakulya B.; Varga S.; Csámpai A.; Soós T. Org. Lett. 2005, 7, 1967. $\underline{\text { http://dx.doi.org/10.1021/o1050431s }}$ 